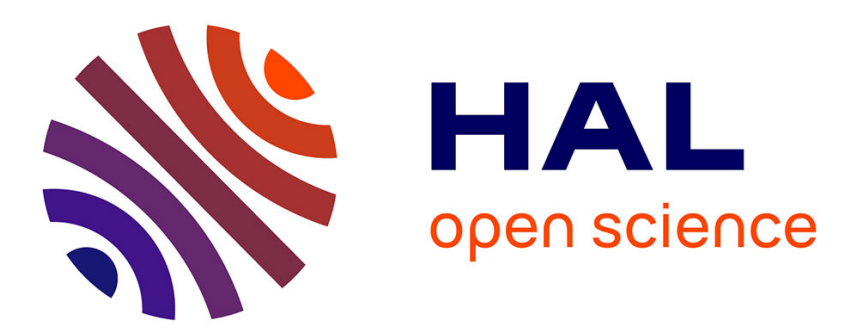

\title{
Reliability of metal/glass-ceramic junctions made by solid state bonding
}

G. Lascar, Daniel Broussaud, Alain Thorel, Georges Cailletaud, J. Roland

\section{To cite this version:}

G. Lascar, Daniel Broussaud, Alain Thorel, Georges Cailletaud, J. Roland. Reliability of metal/glassceramic junctions made by solid state bonding. Journal de Physique Colloques, 1986, 47 (C1), pp.C1139-C1-145. 10.1051/jphyscol:1986120 . jpa-00225548

\section{HAL Id: jpa-00225548 https://hal.science/jpa-00225548}

Submitted on 1 Jan 1986

HAL is a multi-disciplinary open access archive for the deposit and dissemination of scientific research documents, whether they are published or not. The documents may come from teaching and research institutions in France or abroad, or from public or private research centers.
L'archive ouverte pluridisciplinaire HAL, est destinée au dépôt et à la diffusion de documents scientifiques de niveau recherche, publiés ou non, émanant des établissements d'enseignement et de recherche français ou étrangers, des laboratoires publics ou privés. 


\title{
RELIABILITY OF METAL/GLASS-CERAMIC JUNCTIONS MADE BY SOLID STATE BONDING
}

\author{
G. LASCAR, D. BROUSSAUD*, A. THOREL*, G. CAILLETAUD* and \\ J. J. ROLAND
}

\author{
QUANTEL, 17 Avenue de 1'Atlantique, F-91402 Orsay, France \\ * Centre des Matériaux de 1 'Ecole des Mines de Paris. B.P. 87. \\ F-91003 Evry Cedex, France
}

\begin{abstract}
Résumé - L'assemblage par diffusion dit par thermo-compression permet de réaliser des liajsons céramique-métal étanches à l'hélium. Ce procédé engendre cependant des contraintes résjduelles d'origine thernique sous l'action desquelles les défauts de la céramique peuvent se propager et conduire à la rupture djfférée de l'assemblage. Ce phénomène est mis en évidence sur des assemblages vitrocéramique/Al/Invar où une meilleure fiabilité est assurée par une réduction des défauts de surface.

Abstract - The solid state diffusion bonding leads to helium-tight ceramicmetal junctions. However this technique induces residual stresses due to expansion mismatches which may cause ceramic flaws to propagate hence junction delayed failure. This phenomenon is evidenced on glass-ceramic/Al/Invar junctions from which a better reliability is ensured by a reduction of surface flaws.
\end{abstract}

\section{I - INTRODUCTION}

The fabrication of electro-optical components of high quality and reliability lead us to achieve metal-ceramic junctions by solid state diffusion bonding. The dimensional stability required for such components dictated the selectjon of near-to-zero thermal expansion coefficients for the materials to be joined namely a glass-ceramic and a ferronickel alloy. The junction is expected to be helium-tight and to remain so after 20000 hours' operatjon in addition it should hold temperature up to $200^{\circ} \mathrm{C}$ and resists thermal shock from this point down to $-50^{\circ} \mathrm{C}$. In order not to affect the glass-ceramic properties the joining process temperature should not exceed the transition point shown to be around $820^{\circ} \mathrm{C}$, therefore techniques such as brazing or glass soldering are to be avoided.

Soljd state diffusion bonding using aluminjum as intermediate material has been proved in the past to be very efficient in the joining of glass, sapphire or alumina to metal /1/, /2/. Thjs technique was lately extended to non-oxide ceramics and shown to allow heat and thermal shock resistant junctions $/ 3 /$. Fowever the high thernal expansion of aluminium and of metals relatively to ceramics is expected to yjeld residual stresses that may cause catastrophic fajlure after cooling or after thermal cycling.

The present study was undertaken after the observation of delayed fajlures of glass-ceramic/metal junctions without application of additional stress. It aims at the determination of the stress field thermally induced after the joining process and then allowing for the sensitivity to slow crack growth of the glass- ceramic the surface defects were suspected to play a major role on the junction reliability. 
II - EXPERIMENTAL

1. Joining technique. The solid state diffusion bonding consists in interposing a metal gasket between the ceramic and metal surfaces to be bound. The sajd gasket $j s$ then plastically deformed by rapidly squeezing the assembly at a temperature ranging from 0.5 to $0.9 \mathrm{Tm}$ ( $\mathrm{Tm}=$ melting point of the intermedjate metal). The bonding is due to various interface reactions depending upon the materials and the joining parameters.

In our case a low expansion glass-ceramic invar-type ferro nickel alloy using an aluminium ring of hexagonal cross section. The surfaces to be in contact were ground flat up to a polish acceptable for helium-tightness and cleaned. Prior to joining the components were thermally treated in order to relax the residual stresses and to get some primary recrystallization.

The bonding achjeved at about $500^{\circ} \mathrm{C}$ in flowing nitrogen added with 10 \% hydrogen, under a compressive load ranging from 20 to $60 \mathrm{KPa}$. The strain rate ( $\left.10^{-4} \mathrm{~m} . \mathrm{s}^{-1}\right)$ is high enough to break the surface alumina on the ring. Bonding then occurs between fresh aluminium and the glass-ceramic via oxido-reduction and friction adhesion processes on one side and between aluminium and metal via diffusion on the other side. There might be some diffusion between aluminium and the glass-ceramic but it is hardly detectable by conventional microprobe analysis. In comparable experiments conducted elsewhere /4/ some diffusion was outlined on a very short range via SIis analysis. This interface reaction aspect is under further investigation and will be discussed elsewhere.

The schematic of the technique is shown on Fig. 1, the details of the process have been presented elsewhere /5/, the aspect ratio of the aluminium ring was varied from 1 to $\approx 20$ by the deformation process- and an electro-optical assembly thus made is also shown $/ 6 /$.
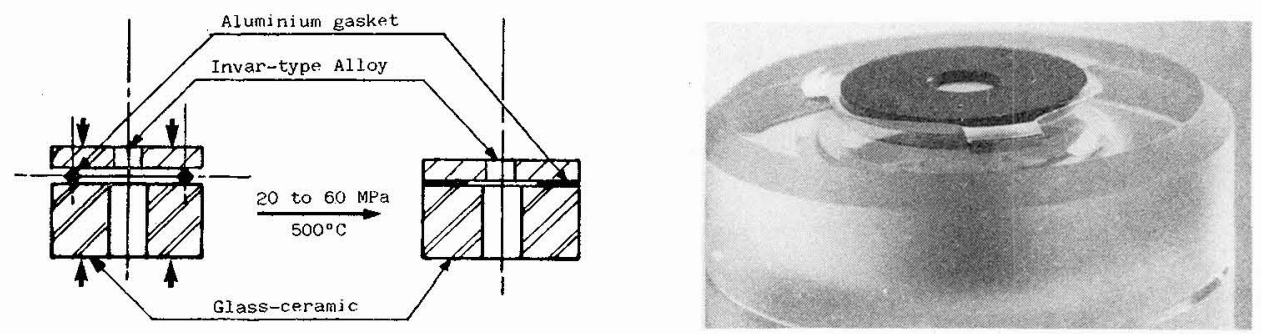

Fig. 1 - Schematic of the bonding technique and view of an electro-optical assembly.

2. Reliability of the junction. It has been observed that from a population of 40 junctions achieved according to the same bonding procedure 7 of those perished by delayed fracture of the glass-ceramic after different periods of time - from 1 to 600 hours - though all 40 were found to be helium-tight after joining. The remarkable fact is that all those 7 were obtained from glass-ceramic parts the surfaces of which had been only grourid whereas all polished surfaces yielded junctions with lifetimes over 10000 hours. Table I summarizes those observations, all survivors could resist the $200^{\circ} \mathrm{C}$ thermal shock test.

(1)

Zerodur from schott : 70 to 75 wt $\%$ \& eucruntite and glass for balance. 


\begin{tabular}{|l|c|c|c|}
\hline Surface preparation & $\begin{array}{c}\text { Defect maximum } \\
\text { size } \mu \mathrm{m}\end{array}$ & $\begin{array}{c}\text { Number of } \\
\text { junctions }\end{array}$ & $\begin{array}{c}\text { Lifetime } \\
\mathrm{h}\end{array}$ \\
\hline Ground & 30 & 1 & $<1$ \\
& & 1 & 3 \\
& & 1 & 168 \\
& & 240 \\
& & 1 & 264 \\
& & 13 & $>276$ \\
& & & $<10^{2}$ \\
& & 20 & $>10^{4}$ \\
\hline
\end{tabular}

Table I - Junctions lifetimes observed after bonding vs surface preparation

Starting from these considerations we came up with the idea that delayed fracture could pertain to some crack growth phenomenon - as previously observed for sodalime-silica glasses in moisture-containing atmosphere /7/. connected with the presence of defects resulting from the surface finish of the glass-ceramic. The observation of a fractured specimen such as shown in Fig. 2 js consistent with this idea, it can be seen than the fracture initiated from the surface and propagated in the body deviating towards the center hole of the specimen by contouring the zone underlying the interface.
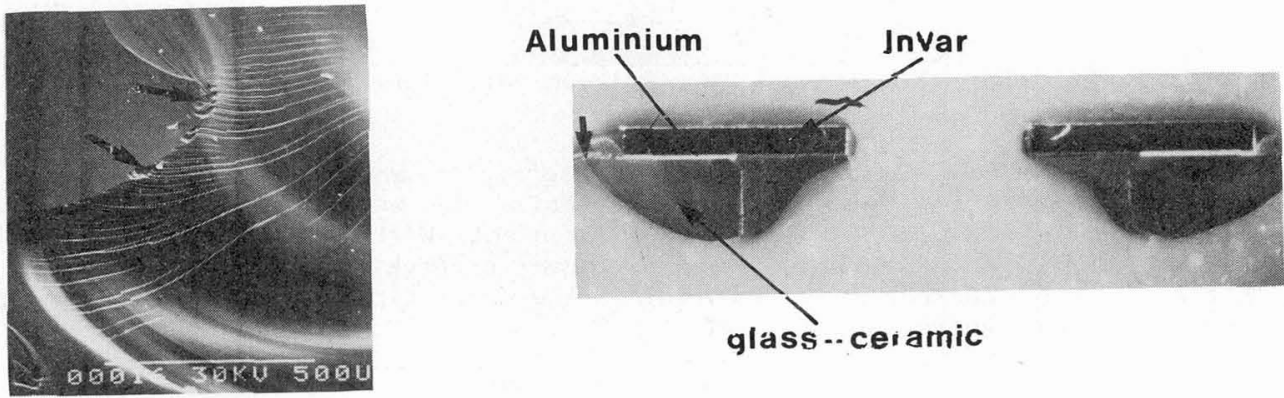

Fig. 2 - Fractography of the glass-ceramic and cross section of the fractured metal/glass-ceramic junction.

Since no additionnal stresses have been appljed onto the specimens after joining one should suspect residual stresses resulting from the process to be responsible for the crack propagation in the glass-ceramic.

3. Mechanical caracterization of the glass-ceramic. Since the above-mentjonned stresses are expected to be complex, different testing techniques have been used to determine the failure stress of the glass-ceramic. Table II gives the values obtained vs the testing mode and comparable results allowing for the surface finish are also given. It is to be noted that the strength level is reduced by a factor of 2 when the surface is as ground instead of polished. Optical microscopy revealed defects of up to $30 \mu \mathrm{m}$ and $10 \mu \mathrm{m}$ in size respectively, which is consistent with the difference of strength level. 


\begin{tabular}{|c|c|c|c|}
\hline Testing mode & Surface preparation & $\begin{array}{c}\text { Failure stress } \\
\text { MPa }\end{array}$ & $\begin{array}{c}\text { weibull } \\
\text { parameters } \\
\text { m }\end{array}$ \\
\hline Shear & Ground \\
Compression & Polj.shed & $65 \pm 15$ & \\
$\begin{array}{c}\text { 3pt bending } \\
\text { biaxial } \\
\text { 4pts bending }\end{array}$ & Polished & $614 \pm 14$ & \\
\hline
\end{tabular}

Table II - Strength characteristics of the glass-ceramic vs surface preparation.

The critical stress intensity factor $\mathrm{K}_{\mathrm{IC}}$ has been determined using three techniques, Vickers indentation - direct /8/ and post flexure strength /9/ - and double torsion /10/, values between 0,6 and $1,15 \mathrm{MPa} \cdot \sqrt{\mathrm{m}}$ were obtained.

The sensitivity to slow crack growth has been investigated using the double torsion technique $/ 7 /, / 10 /$ with $80 \times 40 \times 5 \mathrm{~mm}^{3}$ plates (Fig. 3) in atmospheres containing from $16 \%$ to $100 \%$ humidity. Direct visualization of crack extension was performed. Resulting $V=A K_{I}$ curves that expresses the crack propagation rate $\frac{d a}{d t}$ vs stress intensity factor $K_{I}$ derived from the formula :

$$
\mathrm{K}_{I}=\mathrm{P} \mathrm{w}_{\mathrm{m}}\left[\frac{3(1+v)}{\mathrm{w} \mathrm{d}^{3} \mathrm{~d}_{\mathrm{n}}}\right]^{\frac{1}{2}}
$$

where $P$ is the applied load and $v$ the Poisson ratio (see Fig. 3 for the other terms) are also presented.

$A$ and $n$ values were calculated by linear regression and found to be 0,71 and 16,8 respectively, these parameters thus characterize the sensitivity of the considered glass-ceramic in a moisture containing environment. Wether the latter is satured or not does not affect to a great extent the crack propagation rate, this is consistent with the fact that the chemical potential at the crack tip is rather constant whatever the overall OH-concentration.
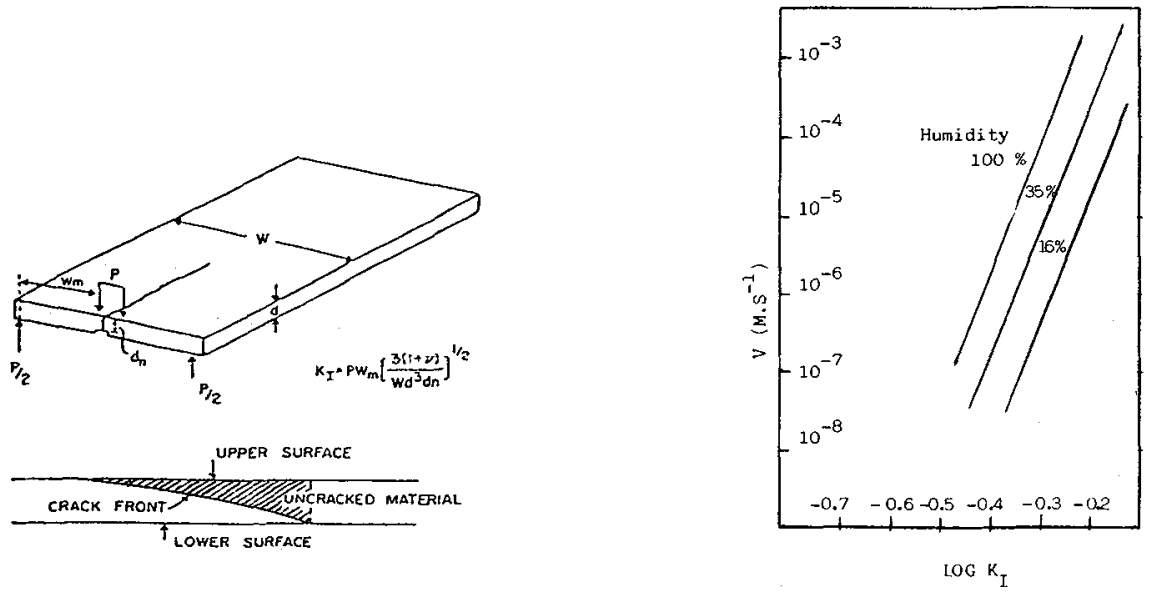

Fig 3 - Double torsion specimen used for the determination of $K_{I}$ and $K_{I}$ (V) curves obtained in various moisture - containing environments.

At this stage it is possible to predict the lifetime of the junction using the weibull distribution parameters (see Table II), in the formalism derived from Griffith's Law. 
Thus Time to Failure $(t)$ vs Probability of rupture at constant applied stress ( $\left.\sigma_{a}\right)$ can be expressed as follow :

$$
t=\frac{2 \sigma_{0}^{n-2}}{\sigma_{a}^{n} \pi \cdot A(n-2) K_{I C} n-2}\left[-\frac{\ln \frac{1}{1-p}}{\frac{s}{m+1}}\right]^{\frac{n-2}{m}}
$$

where $m$ and $\sigma_{0}$ are the Wejbull parameters, $A$ and $n$ the crack growth parameters and $P$ the probability of rupture.

Taking $\mathrm{m}=7,8, \sigma_{0}=43,4 \quad \mathrm{~A}=0,71 \quad \mathrm{n}=16,8 \quad \mathrm{~K}_{\mathrm{IC}}=0,61 \mathrm{MPa} \cdot \sqrt{\mathrm{m}} \quad \mathrm{S}=240.10^{-6} \mathrm{~m}^{2}$ allow to plot strength-Probability-Time (SPT) diagrams as shown on Fig. 4. which pertain to polished glass-ceramic specimens. They show for example that under a tensile stress of $40 \mathrm{MPa}$ the glass-ceramic has $10 \%$ failure probability after 1000 hours $\left(\simeq 4.10^{6} \mathrm{~s}\right)$.

The knowledge of the stress level and direction then appeared of prime importance to assess the reliability of the junction.

\section{III - STUDY OF THE RESIDUAL STRESS FIELD AFTER JOINING}

The first approach consisted in considering the Evans' relationship applied for thermal elastic stresses in a body submitted to a thermal shock :

$$
\sigma=\frac{E \alpha \Delta T}{1-v}
$$

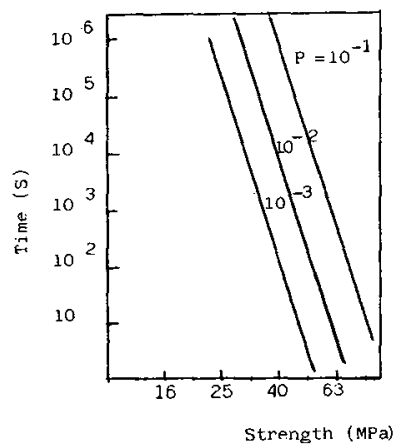

Fig. 4 - SPT diagrams for the glass-ceramic.

It can be shown that thermal stresses jnduced by the expansion mismatch after bonding in the joined assembly may be expressed as follow $/ 5 /$.

$$
\sigma=E \cdot \alpha \cdot \Delta T \cdot \frac{e}{h} \cdot K
$$

where $\mathrm{E}=$ Young's modulus

$\alpha=$ mean expansion coef. of the metal.

$e=$ thickness

and

$h=$ contact $w i d t h$

$\Delta \mathrm{T}=\mathrm{T}$ process $-\mathrm{T}$ reference

$\mathrm{K}=$ geometry factor bound to the metal substrate thickness.

This analytical formula allowsthe calculation of the maximum stress thermally induced at the interface. Depending upon the thickness of the metal substrate - from $0.5 \mathrm{~mm}$ to $1 \mathrm{~mm}$ - that affects the value of $\mathrm{K}$, we have calculated stress values ranging from 50 to $160 \mathrm{MPa}$ (the thicker the metal the higher the stress). Though this approach 
gives some idea of the stress level it doesn't give any jndication on both the distribution and the direction of stresses and doesn't take account of the behaviour of the intermediate aluminium layer - which seems more critical for in some cases the calculated stress is over the yield stress of the metal itself.

Finite element analysis was then carried out for further refinement of stresses evaluation using the values of $E$, $v$ and $\alpha$ shown in Table III for the three components to be bound. The analysis was done for bidimensional and axisymetrical modes, with linear displacement. The limit conditions were taken as follow:

- elastic behaviour for metal and ceramic substrates with no temperature dependence.

- allowance was made for the plastic behaviour of aluminium, consjdered as isotropic and non temperature-dependent.

- the stress is pure thermal with $\Delta \mathrm{T}=500^{\circ} \mathrm{C}$.

The basic mesh corresponding to the actual electro-optical component is shown on Fig. 5 along. with the resulting isostress lines. The stress analysis then showns that normal stresses are found near the outer cylindrical surface of the glass-ceramic substrate whereas compressive stresses are outlined around the central bore.

\begin{tabular}{|c|c|c|c|}
\hline Materials & $\begin{array}{c}\text { Young's } \\
\text { modulus } \\
\text { E (GPa) }\end{array}$ & $\begin{array}{c}\text { Poisson's } \\
\text { ration } \\
u\end{array}$ & $\begin{array}{c}\text { Thermal expansion } \\
\text { coefficient } \alpha(20-500) \mathrm{k}^{-1}\end{array}$ \\
\hline Invar & 135 & 0,32 & $6.5 .10^{-6}$ \\
Al & 78 & 0,3 & $24.10^{-6}$ \\
Glass/ceramic & 95 & 0,25 & $\simeq 10^{-8}$ \\
\hline
\end{tabular}

Table III - Physical properties of the three materials to be solid state bonded.
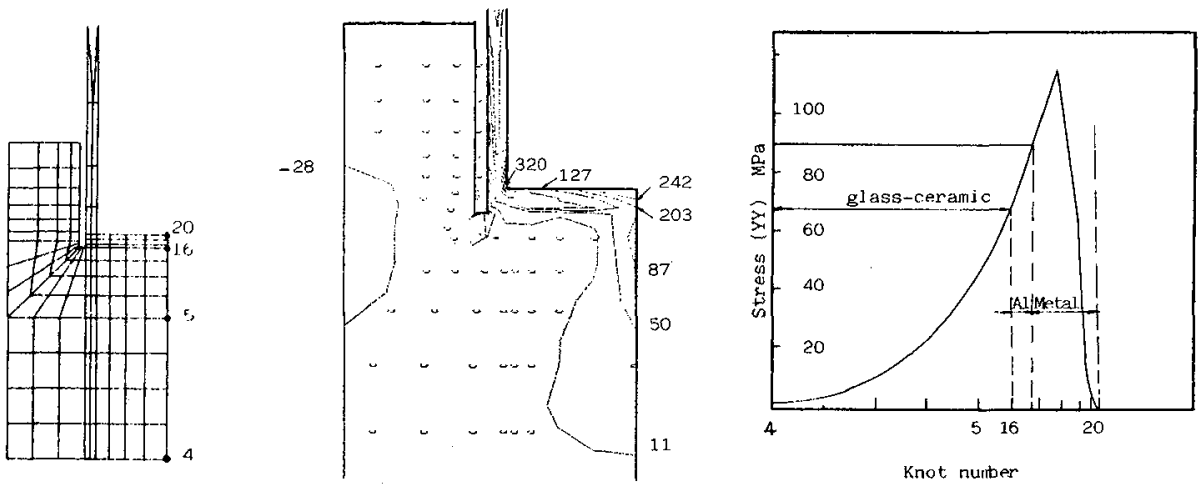

Fig. 5 (Left) - Stress field analysis of the ejectro-optical assembly after solid state bonding main stress in MPa, negative for compressjve. (Right) Tensile main stress calculated along the external generatrix.

The analysis of principal stresses located at the interface revealed high levels of stress in the aluminium layer, which are consistent with the plasticj.ty hypothesis on stress relaxation. As for the glass-ceramic substrate values ranging from 20 to $80 \mathrm{MPa}$ were found depending upon the stress mode and the location. Therefore, although the stress level is reduced by the creep of aluminium, the glass-ceramic appears to be the siege of residual stresses likely to induce slow crack growth.

As a conclusion we could confirm that the observation of delayed fracture of glass-ceramic substrates after joining is consistent with the fact that under the simultaneous action of humidity in ambiant air and residual stresses a slow crack propagation is enhanced. The influence of the surface preparation is of prime importance on the crack injtiation and a careful polish may be sufjcient to improve 
lifetime to a large extent. The reliability of junctions achieved by solid state bonding can be better assessed through a finer stress field analysis.

\section{REFERENCES}

/1/ Kessler J.R., USP, N. 545447.

/2/ Klomp J.T., Welding Journal 50, (1971), 88.

/3/ Broussaud D., Wicker A., Magnet J.L., Special Ceramics 7, 31, (1981), 19.

/4/ Wicker A., Darbon P., and Grivon F., Proc. of International Symposium on ceramic components for engine, Japan, (1984), p. 716.

/5/ Lascar G., Mémoire CNAM, Paris, 22 mars 1984.

/6/ Lascar G., and Roland J.J., Brevet n० 84 02302, (1984).

/7/ Charles R.J., and Hillig W.B., U.S.C.V., Charleroi, (1962), p. 511.

/8/ Anstis G.R., Chantikul P., and Lawn B.R., Marshall P.B. J. Am. Cer. Soc., Vol. 64, $9,(1981)$, p. 533 .

79/ Chantikul. P., Anstis G.R., Lawn B.R., and MarshalI D.B., ibid p. 539.

/10/ Boussuge M., Inghels E., Lamon J., Rev. Int. Hautes Temp. Refrac., Vol. 19, $(1982)$, p. 185 . 